\title{
Organizational Culture and Masculinities in a Startup Company in Finland'
}

I Katri Pöllänen ${ }^{2}$

PhD candidate, University of Helsinki, Department of Cultures, Finland

\begin{abstract}
This article explores the organizational culture of the startup scene in Finland. Startup companies offer an interesting setting for research, because their organizational culture, hierarchy and power structures differ from those of large traditional organizations. The method used in this study was an organizational ethnography in a startup company in Finland, which included participant observation, and interviews with employees. The organizational culture of the startup was informal, relaxed, low in hierarchy, and employees had autonomy for deciding on their working times and locations. Masculinities were visible in the organizational culture of the startup company in the form of 'harsh' language and rambunctious humor, men changing their behavior and discussion topics when women were around, and managers communicating more aggressively with men than with women. The results further showed that gender was a criterion for inclusion and exclusion. The research concludes that startup companies are not gender-neutral spaces.
\end{abstract}

\section{KEYWORDS}

Startup / organizational culture / doing gender / masculinities / inappropriate behavior / Finland

\section{Introduction}

he purpose of this article was to explore the organizational culture of the startup scene in Finland from a gender perspective. In the Nordic context, research on organizational culture and gender has mainly been conducted in large companies, and in industries such as pharmaceutical and technology industries (see Alvesson \& Svegninsson 2008; Wahl 2014). Scientific research is lacking on organizational culture in small, newly founded innovative companies such as startups. Startups are not small versions of large companies (Blank \& Dorf 2012); they have their own organizational culture and ecosystem, referred to as a startup culture and startup ecosystem (Tripathi et al. 2019). According to popular narratives in newspapers and magazines, the organizational culture of startups is informal and playful (Hyrkäs 2016). Furthermore, power structures and hierarchies differ in technology-driven small innovative companies with high growth intentions and traditional, established companies. Startups usually have limited resources and focus on delivering the product (Sutton 2000). They are subject to multiple influences from investors, customers, partners and competitors, and these influences might make them have to change or readjust (ibid.).

There is no single consensus on the definition of startups, but common aspects of the definitions are that the organizations are young, relatively small and designed to grow

\footnotetext{
${ }^{1}$ You can find this text and its DOI at https://tidsskrift.dk/njwls/index.

${ }^{2}$ Corresponding author: katri.pollanen@helsinki.fi.
} 
fast (Kotiranta et al. 2016). Blank and Dorf (2012) define startups as scalable, repeatable and profitable business models. Ries $(2017,27)$ argues that startups also include the aspect of creating a new product 'under the conditions of extreme uncertainty'. This research builds on the definition of startups from the descriptions above: the startup observed in the study was young (under 10 years old), small (under 50 workers) and an innovative, growth-oriented technology venture (Kollmann et al. 2016; Kotiranta et al. 2016; Lahtinen et al. 2016).

Recognizing the context of startup companies is relevant when researching organizational culture, as startup ecosystems differ among countries. The startup ecosystem refers to 'the phenomenon in which startups and their supporting elements interact in an environment that is built to foster these startups' development and growth' (Tripathi et al. 2019, p. 56). The context of this study is Finland, where startups have good access to the latest technologies and venture capital and are well connected with other founders, investors and experts (Baller et al. 2016). It is estimated that 4000-5000 new startups are founded every year in Finland (Lahtinen et al. 2016). Approximately $70 \%$ of new startups survive the time span of five years, by which time their number of employees has doubled. In Finland, the main source of financing for startups companies are Business Angels (56\%), Venture Capital (44\%), incubators or accelerators $(76 \%)$ and bank loans (32\%), combined with bootstrapping (52\%) (Kollmann et al. 2016). Thinking about gender, the startup scene and its funding is interesting: female-founded startups in Europe receive only 3\% of Venture Capital funding, making female-led startups a minority (Atomico 2018).

The aim of this study was to examine the organizational culture in a Finnish startup company, and to explain how startup companies, the organizational culture of which differs from that of traditional companies, are also embedded with gendered practices. This study aimed to answer the following research question: 'What elements contribute to the organizational culture of startup companies, and how is the culture embedded with gendered practices?'

The structure of the article is as follows: First, I introduce the theories behind organizational culture, doing gender and masculinities in work organizations, and organizational culture and gender in the context of technology and startup companies. Second, in the Methods section, I describe ethnographic research design, the context of my study, the data and analyses, and research ethics. Following this, in the Results section, I report on the organizational culture in the observed startup company, on which I then expand in the Discussion section.

\section{Organizational culture}

Organizational culture consists of patterns of shared basic assumptions learned by the members of the organization (Schein 2010). Schein (2010) proposes that culture consists of three levels: (1) Artifacts; (2) Espoused beliefs and values; (3) Basic underlying assumptions. Artifacts include everything you can see, hear and feel when encountering a new culture. Espoused beliefs and values refer to the organization's beliefs and values. These beliefs and values reflect someone's, typically the founder's, original beliefs and values, which turn into collective beliefs and values. Basic underlying assumptions consist of taken-for-granted beliefs and values. These assumptions determine, for example, 
behavior, office spaces and architecture, and dress codes (Schein 1983). Furthermore, sub-cultures may arise within organizations, because different groups in the organization may express different values (Alvesson \& Svegninsson 2008).

In new organizations, the developing organizational culture has to cope with internal problems of creating a set of rules and external problems of adaptation and survival (Schein 1983). Problems of internal integration include common language use; group boundaries and criteria for inclusion and exclusion; criteria for allocation of power and status; and criteria for intimacy, friendship and love (ibid.). External problems include developing a consensus on the primary task, core mission and goals of the organization, and on what kind of repair strategies to use when the group does not accomplish these goals (ibid.). Schein $(1983,2010)$ highlights that the founders shape the organizational culture, because they bring their own assumptions to these newly founded organizations. Founders often have a theory on how to succeed, based on their previous experience in the culture in which they have grown up (ibid.). The organizational culture will reflect the interaction of the assumptions and theories of the founder(s) and what the group learns from its own experiences (ibid.). In the European startup scene, founders are usually men (Kollmann et al. 2016). Thus, male founders play a crucial role in shaping the organizational culture of startup companies.

Organizational culture guides what is seen as appropriate and inappropriate behavior at work. Inappropriate behavior encompasses a wide range of harmful behaviors, such as emotional abuse, bullying and ostracism. According to Sanderson's (2017) research on ostracism, organizational culture can promote the inclusion or exclusion of employees. In her research, she found that participants who had experienced ostracism expressed that the culture of their workplace, and/or the management supported ostracism. The Finnish Centre for Occupational Safety defines inappropriate behavior at work as 'negative behavior in the workplace that is not in line with good conduct and proper manners. It may mean a one-off venting of emotions/eruption or continuous, systematic and intentional actions.' Neuman and Baron (2005) also highlight that intention to harm defines a bully, but that not all inappropriate behavior is intentionally harmful. Furthermore, Lutgen-Sandvik (2003, 472, 493) showed in her research on employee emotional abuse, which can be defined as a 'repetitive, targeted, and destructive form of communication directed by more powerful members at work at those less powerful', that abuse cycles are not due to an individual 'problem employee', but to the norms of the organizational culture.

\section{Doings of gender and masculinities in work organizations}

Gender is a key concept to address when researching organizational culture, because previous research has shown that work organizations are gendered (Acker 1990; Alvesson \& Billing 2009; Martin 2003). In this article, I will be analyzing the doings of masculinities as part of the organizational culture in the light of previous research. According to West and Zimmerman (1987) gender is not a set of traits, but a product of social doings. The essence of doing gender is creating differences between genders that are not due to natural, essential or biological reasons (ibid.). Butler $(1999,33)$ argues that gender is performative: 'gender is performatively produced and compelled by regulatory practices of gender coherence'. Gendered performance has become pervasive and taken 
for granted and is rarely questioned (Bird 1996; Ridgeway 1997). For example, it is often said that 'boys will be boys' and 'men will be men' thus men continue 'doing masculinity' by behaving according to the masculine norm (Bird 1996). Researching masculinities is important, because men usually have higher status, legitimacy and power in organizations. Thus, their behavior shapes the context for the organizations' employees (Martin 2001).

Acker $(1990,146)$ defines gendered organizations as 'advantage and disadvantage, exploitation and coercion, action and emotion, meaning and identity, are patterned through and in terms of a distinction between male and female, masculine and feminine'. The gendering of organizations appears in five processes that interact in the same reality: the construction of gender divisions, such as the division of labor, power, and allowed behavior; the production of symbols and images that reinforce or oppose gender divisions; the interactions between individuals that enact dominance and submission; the production of gendered individual identities; and the ongoing processes of creating and conceptualizing social structures (Acker, 1990). Organizational theory is also gendered: Mainstream reviews and major contributions to organizational theory have ignored gender, and research conducted by women is lacking in the mainstream research of organizational theory (Martin 1994). This has affected which questions have been raised and answered in research (ibid.).

Masculine values and assumptions are embedded in the culture of organizations (Collinson \& Hearn 1994). They include individualism, aggression, competition, sport, and drinking (ibid.). In all-male workplaces, for instance, beer-drinking and the objectification of women highlight the masculine culture of the organization (Alvesson \& Billing 2009). Men may joke crudely with each other and it is assumed that 'real men' can laugh at themselves and take insulting nicknames (Collinson 1988). When women enter the workplace, men believe they need to 'clean up their language' (Alvesson \& Billing 2009). Conversations that objectify women are less likely to be carried out or then shift when a woman joins the interaction (Bird 1996). During male homosocial conversations, people of other genders tend to be referred to as 'them' or the 'other' (Bird 1996).

Collinson and Hearn (1994) name five types of masculinities embedded in organizational practices: authoritarianism, paternalism, entrepreneurialism, informalism and careerism. In the case of startup companies, it is important to explore the form of entrepreneurial masculinities. Entrepreneurialism 'articulates a "hard-nosed" and highly competitive approach to business and organization', which prioritizes performance levels, budget targets and new markets (Collinson \& Hearn 1994, 14). The performance of employees is likely to be monitored and evaluated. Male managers identify with similar men, who are competitive and willing to work long hours to meet tight production deadlines, thus excluding men who are not 'man enough', and most women (ibid.). Furthermore, it is likely that young men are more willing to invest their time in the company than older men (ibid.). Young people may have fewer responsibilities outside working life, such as family obligations (Azoulay et al. 2018).

A recent literature review on men doing and undoing gender at work by Kelan (2018) highlights four ways of doing gender and masculinities in work organizations: men creating connections with other men; men distancing themselves emotionally and socially from women; men impressing others; and men displaying heroism. Men do gender by creating connections with other men by, for example, bonding through sexually objectifying women, mocking and using foul language, identifying with other men due 
to similarity, and supporting other men (ibid.). Men distance themselves from women by publicly criticizing women, ganging up on and excluding women, displaying hostility toward women, being absent and undermining women, and associating women with their wives (ibid.). Men try to impress other men by exercising domination over others, vying for attention, occupying spaces, and promoting their talents as exceptional (ibid.). Men display heroism by applauding other men's extreme presenteeism, being task-oriented, and using others' efforts and taking credit for them (ibid.).

\section{Organizational culture and gender in technology and startup companies}

Companies' founder(s) play a crucial role in shaping organizational culture (Schein 1983, 2010). In Finland, the typical founder of a startup is a young Finnish male: $84 \%$ of founders are men and $16 \%$ women (Kollmann et al. 2016). The average age of a startup founder in Finland is 26, which is the lowest average in European countries (ibid.). Approximately $45 \%$ of founders are under 35 years old. In terms of ethnicity, the majority of startup employees are Finnish $(79 \%), 11 \%$ of employees come from other European countries, and 10\% come from outside Europe (ibid.). These statistics may reveal a lack of diversity in the Finnish startup scene.

Hyrkäs' (2016) findings indicate a problem in the startup job market labelled the 'cult of right fit', because flat organizations ensure that work gets done by hiring likeminded people. This often results in hiring employees who are similar to the founders and has led to a 'brogrammer' culture, into which women might have problems integrating. This is an example of homosociality, which means preferring the company of the same sex (Lipman-Blumen 1976, 16). For instance, a study in Sweden showed that male managing directors indeed practice homosociality during recruitment processes by preferring candidates of the same gender (Holgersson 2013). Homosociality also excludes men who do not meet the standards of the setting due to, for example, their age or personal characteristics, such as not being predatory or 'man enough' (Collinson \& Hearn 1994; Lipman-Blumen 1976).

As regards the technology industry in general, studies have shown that women are a minority, might have trouble fitting in to a male-dominated workplace, and may lose their authenticity in such settings (Hewlett et al. 2008; Marlow \& MacAdam 2012). Marlow and MacAdam's (2012) research indicates that women may start acting 'tough' to fit in and be included in 'boys' talk' in a male-dominated business incubator. A study of women in the technology industry in the United States showed that $64 \%$ of women had experienced sexual harassment; $27 \%$ of women believed that their male colleagues see women as less capable than men, $46 \%$ perceived bias in performance evaluation and $14 \%$ received unwanted attention for their feminine appearance (Hewlett et al. 2008). The study further revealed that $55 \%$ of women had started to behave similarly to men by adopting attitudes that downplay and underestimate other women (Hewlett et al. 2008). This type of 'macho' culture can be hostile toward women, as it may lead to their exclusion (ibid.). Furthermore, technology companies often value youthful family-free workers, which tends to be more alienating for women than men (Wynn \& Correll 2018).

Wynn and Correll (2018) explored university recruitment sessions for startup companies and found that company representatives enforced gender stereotypes when 
presenting their companies. This may discourage qualified women from applying. The companies were presented as 'fratty' and 'geeky' and the offices had beer fridges and ping pong tables that communicated a youthful, masculine environment (ibid.). Kinnunen et al. (2017) argue that modern open-office spaces require a youthful body that adopts a playful state of mind. Office spaces contain things that are meaningful to young men, and are made playful with, for example, games consoles, board games or a pool table. Open-office spaces can be seen as being so masculine that it is unofficially understood that the space does not belong to everyone (ibid.). However, matters related to office spaces may have changed during the COVID-19 pandemic, because employees have been advised to work remotely. It is important to note that this research was conducted before the COVID-19 pandemic.

\section{Methodology and contextualizing the 'Tecful' research site}

\section{Ethnographic research design}

This qualitative study used an organizational ethnographic approach. Ethnographic research draws upon the researcher's close observations and involvement with people in a particular social setting (Watson 2012). Organizational ethnography is used as a method to explore organizational culture, behavior, and change (Neyland 2016). The advantage of an ethnography is that it enables in-depth knowledge on the research topic, and it is suitable for exploring new lines of research (Queirós et al. 2017). However, it may be difficult and time-consuming to gain access and permission to conduct an organizational ethnography in an organization and in some cases, researchers have to change the focus of their study because they fail to gain access (Monaham \& Fisher 2015).

\section{Research context}

The fieldwork of this research was conducted in a startup company called 'Tecful' (a pseudonym) in Finland, for one month in May 2019. Tecful is a Helsinki-based enterprise that also operates internationally. It was founded in 2013 and has approximately 30 employees. Access to the startup was gained surprisingly easily and quickly in contrast to examples of other studies; by sending an email to the Chief Operations Manager explaining my research in March 2019. He discussed it in a meeting with all the employees and they decided that the research could be conducted in their company. I had a meeting with this Chief Operations Manager, during which we agreed on when the study could be conducted and discussed the study objectives and about the company. We signed a research contract and a contract for the company. On the first day of the study, I had a meeting with the Chief Marketing Officer and Chief Commercial Officer to discuss and agree on my work tasks.

Tecful, like the majority of companies in the technology industry, is male dominated (Marlow \& MacAdam 2012). Of the 30 employees, five were women. Two of the female employees worked full time at the office in Helsinki, one worked part-time and only came to the office occasionally, and two lived abroad and participated in meetings via an ICT device. A French intern also worked for a few months at Tecful. All the software 
developers were men, and the women worked in tasks related to sales, marketing, events, and product management. The founders and leaders were male.

The office space was open plan with two rooms. The doors were mainly kept open. One side was for the developers, leaders and founders, and the other was for sales and marketing. The developers had their own desks and computers, and the other side had tables and couches. Some of the employees lived elsewhere in Finland or in other countries. They communicated and joined meetings through online platforms. Slack collaboration software was used for in-house communication. Slack also had various chats, such as 'daily' where employees could talk about their work tasks for that day, 'lunch' for discussions related to where to go for lunch, and 'random' for non-work-related topics.

Ethnographic research requires a reflection of how the presence of a researcher may affect the research environment (Korczynski 2011). In this case, a possible bias is that the employees may have behaved somewhat differently when I was around, which is one of the challenges in ethnographic studies in general. I attempted to avoid this bias by using the participant-observatory method, in which the researcher participates in the setting, in this case becoming one of the employees during the study. I worked part time on tasks given by the organization, and part time observing, writing field notes and conducting interviews. I completed my work tasks and wrote my notes mainly on my computer on a Word document, since the majority of the time employees worked on their laptops. This way, I did not draw too much attention to myself, as I was working in similar ways to the other employees. A desk was reserved for me in the leaders' and software developers' room. I could also work in the marketing and sales room on the couch or, if there was space, at a desk. In this room, I felt I was immediately accepted as one of the employees. I was included in discussions related to work and leisure time from the first day of the study. In the leaders' and software developers' room, I had a harder time fitting in. This room was generally quieter, and when the employees discussed matters other than work tasks, usually sports, I was not included. It seemed they perceived me as an outsider in this room, which may be due to my researcher status or other reasons, such as gender or not being interested in the same sports or not having the competence in software development.

\section{Data and analysis}

The organizational ethnographic approach in this study combined the methods of participant observation and thematic interviews with open-ended questions. Participant observation made it possible to obtain an overview of what it was like to work in the startup, their meetings, and communication tools, and to gain insights that might not emerge in interviews of employees from an outsider's point of view. The interviews in turn provided insights into the employees' positive and negative experiences of the organizational culture of the startup. The interview structure used the Critical Incident Technique (CIT), a qualitative tool that aims to analyze people's problems and behavior (Flanagan 1954). This approach requires employees to provide in-depth descriptions of specific events, 'critical incidents', to enable understanding of their thoughts and behaviors (Stitt-Gohdes et al. 2000). The interview questionnaire was divided into three themes: (1) Startup culture; (2) Inappropriate behavior and (3) Ending of the interview. 
The questions related to the startup culture asked the employees to describe the culture in their organization, to give an example or describe a positive and negative experience of the startup culture, and to describe their experience of the significance of gender in the company. In the second theme, inappropriate behavior, the employee was asked whether they had noticed inappropriate behavior in the organization and to give an example of such a situation; whether they had been the target of inappropriate behavior and to give an example of such a situation; to describe what is done in the organization so that people behave appropriately and if someone behaves inappropriately. Situations or 'critical incidents' were further elicited using the CIT question tool (Serrat 2017): What were the events or circumstances that had led to the critical incident? What behaviors of the agents had made these (events or circumstances) a critical incident? What were the outcomes of the critical incident? What are the possible future outcomes if behaviors remain unchanged? What are the possible future outcomes if behaviors change based on lessons learned? The questionnaire ended by asking what kind of startup scene would the employee like to work in and whether they have anything else they wish to raise.

The study data consisted of field notes, a research diary, and thematic interviews of employees $(\mathrm{N}=5)$. The interviews lasted approximately an hour and were audio recorded. Two of the interviewees were women and three were men, their mean age was 35 and they had worked in the company from 2 months to 3 years. The languages of the interviews were Finnish and English. The interviews were transcribed and anonymized. Thematic analysis was used as a tool for analysis (Nowell et al. 2017). In thematic analysis, 'themes are recurrent and distinctive features of participant's accounts, characterizing particular perceptions and/or experiences, which the researcher sees as relevant to the research question' (King et al. 2018, 200). The research diary, field notes, and transcribed interviews were analyzed separately. The first phase of the thematic analysis was familiarization with the data through reading of the research diary, field notes and transcribed interviews. After this, the documents were coded and then clustered into thematic groups based on their descriptions of organizational culture. The following themes were observed and discussed further in the findings: Tecful's structure and working hours, freedom and authenticity, atmosphere and climate, hierarchy, and inappropriate behavior.

\section{Research ethics}

The ethics of ethnographic research particularly concern the positioning of the researcher and the anonymization of the research data (Tallberg 2009). The researcher has multiple identities and positions in ethnographic research (Cunliffe \& Karunanayake 2013). The ethical question that arose in this study was: Who am I, and do I have the right to represent the findings of the setting? I was similar to the research population in that I was a white Finnish person; however, as a woman, I was a gender minority. I came to the research site as an outsider, but in the marketing and sales room, I felt I became one of the workers, an 'insider'. In the leaders' and software developers' room, I perceived myself as different and as an outsider, but overall, during the study I felt like part of the work community. However, I was 'the other' in two ways: I was a researcher and I was female. These factors affected the questions I raised, observed and analyzed.

Gender affects the dynamics of fieldwork in organizational settings (Bell 1999). In this study, I was a female in a majority male setting. Therefore, my gender may have 
affected my access to observe male homosocial conversations and behaviors. This influenced what I was able to observe and the results I am able to draw from the data. However, it remains unclear whether becoming 'one of the lads' enhances the quality of research (Bell 1999). It is important to conduct research in organizations from the perspectives of a female researcher, because only a small number of studies in maledominated settings have been conducted by women (ibid.).

The study was conducted according to the ethical principles of research in the humanities and social and behavioral sciences issued by the Finnish National Board on Research Integrity TENK. As the researched organization was small, anonymization of the data was of utmost importance. The direct identifiers were removed in the transcription and analysis phase and archived without identifiers. Neither the organization nor the employees can be recognized in the data. The employees were made aware of their rights in accordance with the General Data Protection Regulation (GDPR). At the weekly office meeting, all the employees at Tecful were made aware of the purpose of the study, and were invited to participate in the interviews. Participation was voluntary and they contacted me either by coming to speak to me face-to-face or by sending a message. Each interviewee signed a research contract, and received a data protection statement. The participants were informed of the purpose of the interviews and of their right to withdraw from the study at any point.

Due to privacy issues, the positions of the employees are not disclosed; however, the interviewed employees were not founders of the organization. Pseudonyms are not used, the interviewees are only referred to by their gender, due to the startup company being small. As one of the purposes of the study was to explore the doings of masculinities in the organizational culture, stating gender was essential for analytical reasons. An ethical issue was that a Tecful employee should be able to read the article without recognizing any employee. However, the interviewees themselves may have spread information about their participation in the research, which means that anonymity is always limited (Tallberg 2009).

\section{Organizational culture at Tecful startup}

\section{Structure and working hours}

The organizational structures of Tecful were flexible: in terms of working hours, tasks and locations. Working hours did not follow a ' 9 to 5' fixed structure; employees had autonomy to decide when and where they worked. The workdays were usually as follows: Mornings were relatively quiet, I came to the office at 9:00 AM, and approximately five employees were there at that time, after which the others started gradually arriving. Most people were at the office at midday, and after this, employees started leaving the office one after another. Another example of this flexibility was that some employees worked in other parts of Finland or in different countries in Europe and participated in meetings mostly through ICTs.

The employees told each other daily what their work tasks were for the day in the Slack collaboration software. Sometimes they told what time they were coming to the office or if they were working remotely that day. As an example from my field diary notes (22 May 2019): 'One employee apparently has not been able to sleep as he wrote 
at 2 am "sleeping is apparently totally overrated, so I could just as well do some work. Still continuing with new variant view stuff." The first messages in Slack usually arrived between 6 and 7 AM, even though the employees might not have been at the office at the time. One male employee described the flexibility of the startup culture in his interview as follows:

Flexibility is part of the startup culture: flexibility in working hours, flexibility in performing work tasks. Sometimes there are weeks when you have to work overtime, but then you might have other weeks when you do a lot fewer actual work tasks; for example, your work tasks might include planning and thinking about a certain thing. A concrete example from this company is that no one counts presence minutes, or no one wonders if I reply to a message or email on the weekend or at 5:30 AM. (Male employee, interview)

These descriptions show that the employees have freedom and autonomy and no boundaries or limits related to their work tasks and hours. A male employee saw this as a positive thing and further stated during his interview: 'Somehow, insidiously the work becomes a part of your life [...] I believe it benefits both the employee and the company'. As work becomes part of one's life, the boundaries of work and private life become blurred (Karjalainen et al. 2017). During the interviews a female employee told me that it is essential to have time prioritization skills, because there will always be work tasks to be completed, and employees need to be able to draw the lines and boundaries of their working hours and tasks themselves. Therefore, the company hires employees who can give 'more of themselves':

And often you may have to give a little more, it will not be enough to sit at work for 8 hours and try to give your best, and that's why employees are hired who give a bit more of themselves, etc. (Female employee, interview)

This description is in line with the entrepreneurship form of masculinities, which involves managers doing homosociality by recruiting like-minded people, in this case employees who 'are willing to invest their time' in the company (Collinson \& Hearn 1994). Furthermore, this can be interpreted as age discrimination, as it may require neglecting the duties of other social roles outside of working life (Azoulay et al. 2018).

The employees are allowed and required to use their own creativity for work tasks, for example, one employee reported in the weekly meeting that he had created a gift basket and started handing them out to potential new clients. By doing so, he showed his autonomy and used his own way of increasing the likelihood of selling. However, during an informal discussion with three female employees during lunch, they told me that they had received no training for their work tasks, and it was 'the worst when you didn't know that you were supposed to do something in a certain way'.

\section{Freedom and authenticity}

In addition to freedom in terms of working hours, locations, and work tasks, freedom also manifested as the ability to be authentic in the work community. One male employee explained during his interview that 'everyone has the courage to be themselves and it is 
also appreciated'. During the interviews, when asked about the importance of gender in Tecful, the employees did not give gender any significance: Everyone was treated similarly and with respect, and everyone in the company was seen as having equally important roles. A female employee acknowledged that more men work in startups in general, but she did not feel that she was treated differently because of her gender.

To the employees, 'being yourself' also meant that they could dress as they wished and that they did not need to wear 'business casual' attire. From my perspective, the physical appearance of the employees was very similar. The majority were young white males who followed a similar dress code that emphasized a casual and friendly style at work. This can be seen as the 'tech uniform', which is part more generally of the startup entrepreneurship culture (Hyrkäs 2016).

Furthermore, freedom meant being able to say what was on your mind 'without a filter', and not feeling pressured to 'act and say specific things to cater to specific people' (Male employee). Two male employees described the communication as 'harsh like hockey player talk' and 'locker room talk'. During her interview, one female employee stated that they had 'rambunctious humor' at the office. In her experience, no one at the workplace was 'too sensitive' and they accepted this kind of humor: 'Maybe we have the type of people in the company who can tolerate quite 'hard' humor'. These examples show that masculinities are done through the use of foul language and harsh jokes (Collinson 1988; Kelan 2018).

The employees highlighted the freedom of the organizational culture when joking with each other. For example, when one employee complained that someone was stealing his things and said that he needed a locker for his work equipment, the other employees in the sales and marketing room joked that they should also get a timecard for work, and 'a ball and chain' around their ankles. This combined a common workinghour tracking method used in many companies with a symbol that limits freedom.

\section{Atmosphere and climate}

The startup's office spaces were divided into two rooms: one room for the marketing and sales team and the other for leaders and software developers. I perceived the atmosphere in the two different rooms as surprisingly different. In the marketing and sales room, the atmosphere was social, open and inclusive. I was included in discussions, whether they were related to work or leisure time, and I felt comfortable there. However, working in this room had more disruptions. Sometimes, the room was very silent, and you could only hear the typing of keyboards. But then, the silence could suddenly be disrupted when someone received a phone call or when one employee asked another a question. Sometimes they even held meetings with a client in the room, so that anyone in the room could hear what they were discussing and possibly even intervene. The employees often hummed, listened to music or even sang. Sometimes they found other spots in the office building, such as the meeting room if it was not occupied, to work alone or with another employee. This room did not have enough space for all the employees to work at desks, and some had to work on the couches. This suggests that the office spaces were more suitable for younger people, as argued by Kinnunen et al. (2017): modern office spaces may require a 'youthful body'.

In the leaders' and software developers' room, my experiences of the Tecful environment were very different. This room was all male. The employees were silent and focused on their work, and occasionally when they talked, it was about last night's 
football game, and they did not even try to include me in these conversations. I did not feel comfortable about interfering and talking about this either: 'I have been sitting all day without talking to anyone (in the leaders' and software developers' room).' For the first time I felt like an outsider: 'I feel different and isolated' (Field diary, 8 May 2019). Previous research has shown that women may be 'singled out' and have trouble fitting in in a masculine setting (Marlow \& MacAdam 2012). On the other hand, I was more productive in this room, which gave me satisfaction as I worked well on those days.

It seemed hard to believe that two office rooms of the same startup, next to each other, with their doors wide open, could be so different. I wrote about my experiences in the field diary: 'It feels like I am in a different startup compared to my experiences in the beginning of the week' (Field diary, 8 May 2019). The two rooms seemed to have different types of organizational cultures.

\section{Hierarchy and power}

The hierarchy in the startup was low, and employees had direct access to the leaders, who were in the open office spaces among the employees. The employees believed that they were all on the 'same line'; their work title or gender did not matter. This was also shown by a male employee wondering if his manager's title was truly correct: 'For example, in my case, is my manager truly in a management position or is it more like a guiding colleague'. When I asked a female employee about the position of another worker, she answered: 'Well here we are all on the same line anyway'. Some statements made it clear that there was some hierarchy in the organization, for example, another female employee said in her interview: '[...] it also depends on your work position, but the higher you go, the more work there is'.

Behind the scenes, the stakeholders and funders shape the organizational culture of startup companies. In this assumingly low hierarchical organization, the funders still seemed to have the most power and to make the decisions:

\footnotetext{
How a startup evolves depends on the stakeholders' influence, [...] especially if you have 'risk funders', who put more money into the company. [...] Now we have funders who are more actively involved, who set very high goals, [...] so in the last few months getting results has been emphasized, so we can get more money for the firm and grow. So that was extremely demanding. So it affects the work environment, what kind of aims come from the funders. (Male employee, interview)
}

Thus, the funders shape the organizational culture by setting goals for the company. By setting high goals, an organizational culture becomes task-oriented instead of peopleoriented, which can be seen as doing gender and as a masculine feature of an organization (Collinson \& Hearn 1994; Kelan 2018).

\section{Inappropriate behavior}

I discussed appropriate and inappropriate behavior with the employees during the interviews, and they saw the source of inappropriate behavior to mainly be communication: 
receiving negative feedback, the use of harsh language, and exclusion on social media. A female employee perceived that the employees only received negative feedback: 'people are criticized out loud and feedback is given so that others hear it too. And we never hear positive feedback, we are only given negative feedback.' She believed that mistakes are made in the work environment because employees are not trained for the work tasks and have to solve problems without enough knowledge. My own observations concerning feedback differed: I heard a great deal of positive feedback given by the managers in particular. However, the feedback was always combined with swearwords.

'Strong' masculine and 'weak' feminine stereotypes were reinforced by managers speaking more harshly to men than women: one male employee felt that men had to be 'tough' and able to take harsh language from the managers. He reflected on this aggressive behavior, which can be seen as a masculine value (Collinson \& Hearn 1994):

He (a manager) talks differently to women and to men. To men he talks more harshly, to women it's more, let's call it, polite. Because we are men and we can take it, but I felt like this is very aggressive behavior. (Male employee, interview)

These incidents happened when the sales team had not met their sales goals. The employees talked to the manager and expressed that they did not approve of his behavior. Similar incidents occurred again, and the interviewed employee did not believe that the behavior of the manager would change, therefore the employees had to 'increase their tolerance':

People don't change easily, so similar instances occurred again [...]. So basically, what we did is we increased our tolerance $[. .$.$] . You don't take everything so personally [\ldots]$. We understand that people have limitations and weaknesses and moved forward, we don't take everything too hard. Because at the end of the day we need to meet the goals. (Male employee, interview)

In Tecful, gender became a criterion for inclusion and exclusion, as men felt the need to change their behavior when women were around:

Maybe we (men) are more sensitive to what we say in the company [...] we don't just say anything we want, we have to be careful what we say. Because among men [...] we can say harsh things among ourselves, but if there are other people, we might not say these things, because we might be stigmatized. (Male employee, interview)

In his description, this interviewee put women in 'the other' category, which indicates an explicit division between genders, as elaborated by Bird (1996). The female employees did not express such experiences, nor did I notice the atmosphere or conversations changing when I came into a room.

A female employee described coping and adapting to the startup culture as a negative experience. One of her former colleagues had behaved inappropriately, which was one reason why she had difficulties coping. As an example, she told me: 'when I asked for something or when I should have worked together with her, she sometimes said "no, I don't have time", and in a certain way she did not pay attention at all'. This situation 
went on for nearly a year, and it only ended when the colleague found a new workplace. The female employee had later discussed the situation with her other colleagues, and some of them had also had a hard time. The employee's behavior burdened her a great deal, and she stressed that it was not the only factor causing problems related to coping. She perceived that the organization was not necessarily ready to deal with issues of inappropriate behavior. Although, the descriptions seem to imply that the problem went away once the employee left, it was the norms of the organizational culture that allowed the difficult employee to behave the way she did (Lutgen-Sandvik 2003).

Another example of inappropriate behavior arose in one interview when a female employee described a situation in which a male colleague said something degrading about women. Objectifying and undermining women is an act of doing gender (Kelan 2018). However, another male colleague had stepped in and contested the use of that kind of language by saying it was disrespectful. With this act, he was undoing masculinity stereotypes by not approving the oppression of women. However, this could also have been an act of masculinist protection; a masculine man protecting a woman from harm (Young 2003).

A male employee described how social media plays a great role in creating inappropriate behavior within organizations:

Social media has changed communication, also in organizations. It brings new dimensions, such as the possibility of working remotely. It also allows WhatsApp groups etc. to be created within a company [...]. It is a tool that can bring transparency and can make communication easier, but it is also a tool for exclusion, excluding people from discussion.

(Male employee, interview)

The description shows that sub-cultures exist within Tecful. The employee further explained that he knew people had created group chats in Slack, and that he had sometimes himself also been in such groups. He described the communication in these chat groups as 'locker room talk' and 'talking behind someone's back'. He has later regretted participating in such group chats. He further stated that who were included in and excluded from these chat groups varied; sometimes even managers were involved in the groups. On Slack, I noticed that a non-work-related chat was in Finnish, which excluded the employees who did not speak Finnish from these discussions.

Field diary notes (29 May 2019): We speak Finnish at the office, but in Slack and during meetings, the language is mainly English. An exception is the random chat on Slack, where the developers and leaders speak in Finnish. This important 'non-work-related' chat is exclusive to non-Finnish speakers.

\section{Discussion}

The purpose of this study was to explore the organizational culture of a startup company in Finland and to determine how the culture is embedded with gendered practices, using an organizational ethnographic approach. The study supports the view that organizations are gendered, and the results reveal insights into the startup's organizational culture and life.

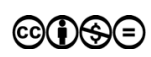


In line with Hyrkäs's (2016) findings, Tecful's organizational culture was informal and relaxed, had a flat hierarchy and direct access to the leaders, who also worked in the open-office area. The flexibility and freedom of the organizational culture were more strongly articulated in Tecful than is often the case in traditional enterprises. Employees had the autonomy to decide on their working hours and locations and to use their own creativity in performing work tasks. Furthermore, freedom meant 'being yourself', being able to talk 'without a filter', being able to dress as you wish, and not being pressured to act in a certain way. It seems that the employees had the freedom to be authentic - which is in line with the startup's style - but at the same time they were expected to fit in with the masculine, youthful culture of the organization. Does everyone have the freedom to be authentic in the startup scene or does the organizational culture exclude people who differ from the majority, such as non-heterosexuals or non-white people? This is an interesting question that future research could explore.

Today, many workplaces require flexibility of both the employee and the organization, thus, the boundaries between private life and work become blurred (Karjalainen et al. 2017). In Tecful, it was believed that both the individual and the company benefits from work becoming a non-detachable part of one's life. The age axis showed that workers were younger - they may have had fewer obligations outside of work and may therefore have been able to invest more time in the company (Azoulay et al. 2018; Collinson \& Hearn 1994). Hiring employees who are similar to the founders and invest their time in the company beyond regular working hours can be interpreted as an entrepreneurship form of masculinities (Collinson \& Hearn 1994).

This study's findings of the youthful, masculine culture of the startup scene support previous literature on the startup technology industry. In line with Wynn and Correll's (2018) research, the youthful, masculine culture was highlighted by rambunctious humor and leadership cursing. During the interviews, the men said they had to be more sensitive when women were around and could not talk as 'harshly' as when among males only. Alvesson and Billing (2009) and Bird (1996) also found that in working life contexts, men feel the need to 'clean up' their conversations when women join the discussion. This can be interpreted as men doing gender by bonding with other men and excluding women from discussions, or as an act of masculinist protection of women from harsh conversations (Kelan 2018; Young 2003). However, some findings differed from previous research. Previous research on the technology industry has shown that women have trouble fitting in (Hewlett et al. 2008; Marlow \& MacAdam 2012). In Tecful, the women felt that they were respected and treated equally to the men, but men felt that they had to be tough and able to take harsh language from their managers 'like a man'. From the perspective of the division of labor (Acker 1990), Tecful leaders were men, and men had the highest positions of organizational power. Acker (1990) argues that organizational practices maintain the power structures of organizations. Therefore, it would be beneficial for further research to determine whether women have similar career development opportunities to men in the startup scene.

The employee's descriptions of inappropriate behavior showed that the behavior under the umbrella term of 'inappropriate behavior' varies. The experiences of inappropriate behavior in Tecful ranged from one-time instances to continuous behavior, and fit the definition of The Finnish Centre for Occupational Safety. The interviewed employees perceived inappropriate behavior to mainly concern communication: negative feedback 
was given so that others could also hear it, communication was often harsh, and exclusion took place in social media. In Tecful, technology platforms were used to form chat groups and to exclude certain people from conversations. As in Sanderson's (2017) study, in which the participants believed that the management supported exclusion of certain employees, in Tecful, the managers were sometimes part of these groups on Slack that excluded some employees. Non-Finnish speakers were excluded from the chat on Slack about non-work-related issues, because the language of the chat was Finnish. In organizations like this, where the boundaries of work and private life are blurred (Karjalainen et al. 2017), it can be seen as inappropriate to exclude non-Finnish speakers from chat about non-work-related topics. Future research could focus more on milder but no less harmful forms of inappropriate behavior, as this research focused mostly on outspoken violent behavior.

The limitation of this ethnographically informed study is that it investigated only one case, and therefore the findings cannot be generalized to apply to all other startup companies (Flick 2002; Suryani 2008). Although the study explored the masculinities embedded in the organizational culture in a male-dominated environment, I was not always able to observe male homosocial behavior. This is often a limitation for women researchers in male-dominated settings (Bell 1999), although for a male researcher, 'male bonding' may in turn impede the critical examination of men and masculinities (Hearn 2013). I interviewed both the male and female employees to gain further information on the masculinities embedded in the organizational culture. I perceived that the employees felt that the interview situation was a safe space in which to openly talk about their experiences. For example, the interviews of male employees revealed masculine behaviors such as managers' aggressive conduct and the exclusion of certain employees from social media groups.

This article is part of a project that explores organizational culture, masculinities and behaviors in startup companies in Finland, and is funded by the Finnish Cultural Foundation. This study served as the theory-building stage for the upcoming research. As the first organizational ethnography in a startup company in Finland, this study offers more in-depth knowledge about the organizational culture of a small, innovative startup company that has a different ecosystem, structure and culture to those of traditional large enterprises. The research contributes to the field of gendered organizations by taking gender into account, instead of taking a gender-neutral approach, and supports the theory that organizations, including startups, are indeed gendered. Tecful received a summary report on the main findings of the study, giving it the opportunity to improve its organizational culture. The findings show what startups are like as employers and can help companies make their organizational culture more inclusive.

Further ethnographic research and multiple case studies on the Finnish startup scene would be beneficial to gain a deeper understanding of the startup culture in Finland as well as in other Nordic countries. Furthermore, it would be beneficial to research other social dimensions such as age and ethnicity, as they may be relevant for gaining a deeper understanding of how intersectionalities are further constructed on the basis of masculinity. It would also be interesting to investigate how the COVID-19 pandemic has affected startup companies' organizational culture and ways of operating.

In conclusion, the results of this study show that the organizational culture of Tecful was youthful, flexible, low in hierarchy, and subject to the influence of stakeholders. 
The culture was embedded with gendered aspects. Gender divisions (Acker 1990) were visible in the work positions of the employees and in hierarchical and power relations, as the leaders and software developers were all men, and the women were mainly positioned in the sales and marketing team. The interactions between individuals were often masculine (Alvesson \& Billing 2009; Collinson 1988; Kelan 2018), described as 'locker room talk' and 'rambunctious humor', and men were more sensitive about what they said when women were present. The office space was more suitable for younger employees (Kinnunen et al. 2017), and the way in which the employees dressed highlighted the youthful and masculine image of the company.

\section{References}

Acker, J. (1990). Hierarchies, jobs, bodies: A theory of gendered organizations, Gender \& Society 4(2): 139-158. doi: https://doi.org/10.1177/089124390004002002.

Alvesson, M., \& Billing, Y. D. (2009). Understanding gender and organizations. $2^{\text {nd }}$ edition, Sage.

Alvesson, M., \& Sveningsson, S. (2008). Organizational culture and change. Changing Organizational Culture: Cultural Change Work in Progress. Oxon: Routledge, 35-50.

Atomico (2018). State of European Tech. Atomico.

Azoulay, P., Jones, B., Kim, J. D., \& Miranda, J. (2018). Age and high-growth entrepreneurship (No.w24489). National Bureau of Economic Research. doi: https://doi.org/10.3386/ w24489.

Baller, S., Dutta, S., \& Lanvin, B. (2016). Global information technology report 2016, Geneva: Ouranos.

Bell, E. (1999). The negotiation of a working role in organizational ethnography, International Journal of Social Research Methodology 2:1, 17-37. doi: https://doi.org/10.1080/ 136455799295168.

Bird, S. R. (1996). Welcome to the men's club: Homosociality and the maintenance of hegemonic masculinity, Gender \& Society 10(2): 120-132. doi: https://doi.org/10.1177\% 2F089124396010002002.

Blank, S., \& Dorf, B. (2012). The startup owner's manual: The step-by-step guide for building a great company. BookBaby.

Butler, J. (1999). Gender trouble: feminism and the subversion of identity.

Collinson, D. L. (1988). 'Engineering humour': masculinity, joking and conflict in shop-floor relations, Organization Studies 9(2): 181-199. doi: https://doi.org/10.1177\%2F0170840 68800900203.

Collinson, D., \& Hearn, J. (1994). Naming men as men: Implications for work, organization and management, Gender, Work \& Organization 1(1): 2-22. doi: https:/doi.org/ 10.1111/j.1468-0432.1994.tb00002.x.

Cunliffe, A. L., \& Karunanayake, G. (2013). Working within hyphen-spaces in ethnographic research: Implications for research identities and practice, Organizational Research Methods 16(3): 364-392. doi: https://doi.org/10.1177/1094428113489353.

Flanagan, J. C. (1954). The critical incident technique, Psychological Bulletin 51(4): 327. doi: https://psycnet.apa.org/doi/10.1037/h0061470.

Flick, U. (2002). An introduction to qualitative research. 2nd ed., Thousand Oaks/London: Sage Publications.

Hearn, J. (2013). Methods and Methodologies in Critical Studies on Men and Masculinities. In B. Pini \& B. Pease (Eds.) Men, Masculinities and Methodologies (pp. 26-38), Basingstoke: Palgrave Macmillan. 
Hewlett, S. A., Luce, C. B., Servon, L. J., Sherbin, L., Shiller, P., Sosnovich, E., \& Sumberg, K. (2008). The Athena factor: Reversing the brain drain in science, engineering, and technology, Harvard Business Review Research Report 10094: 1-100.

Holgersson, C. (2013). Recruiting managing directors: Doing homosociality, Gender, Work \& Organization 20(4): 454-466. doi: https://doi.org/10.1111/j.1468-0432.2012.00595.x.

Hyrkäs, A. (2016). Startup Complexity: Tracing the Conceptual Shift Behind Disruptive Entrepreneurship. Publications of the Faculty of Social Sciences.

Karjalainen, M., Niemistö, C., \& Hearn, J. (2017). 'Pakko painaa pitkää päivää': työn ja muun elämän väliset hämärtyvät rajat tietotyössä ('Forced to do long days': blurring the boundaries between work and life in knowledge work). In Työaikakirja. Into kustannus.

Kelan, E. K. (2018). Men doing and undoing gender at work: A review and research agenda, International Journal of Management Reviews 20(2): 544-558. doi: https://doi.org/ 10.1111/ijmr.12146.

King, N., Horrocks, C., \& Brooks, J. (2018). Interviews in qualitative research, Sage.

Kinnunen, M., Lempiäinen, K., \& Peteri, V. (2017). Konttorista monitilatoimistoksi: työn tilojen etnografinen analyysi (From an office to a multifunctional office: ethnographic analysis of office spaces). Sosiologia 54 (2017): 2.

Kotiranta, A., Pajarinen M., Rouvinen P. (2016). Miltä startupit näyttävät tilastojen valossa? (Characteristics of Finnish startups). ETLA Raportit No 6.

Kollmann, T., Stöckmann, C., Hensellek, S., \& Kensbock, J. (2016). European startup monitor 2016. Universität Duisburg-Essen Lehrstuhl für E-Business.

Korczynski, M. (2011). The dialectical sense of humour: routine joking in a taylorized factory, Organization Studies 32(10): 1421-1439. doi: https://doi.org/10.1177\%2F0170840 611421256.

Kähärä, E., Lehtoranta, T., Lehtovirta, R., Mäkinen, K., Piho, L., Rauramo, P., Somer, A. (2015). Preventing and handling inappropriate behavior in the workplace. The Centre for Occupational Safety. Savion Kirjapaino Oy. Retrieved from https://ttk.fi/files/4645/ Preventing and Handling Inappropriate Behaviour in the Workplace.pdf.

Lahtinen, H., Pekkala H., Halme K., Salminen V., Härmälä V., Wiikeri, J., Lamminkoski, H., Lähde, K., Mikkelä, K., Rouvinen, P., Kotiranta, A., Pajarinen, M., Dalziel M., Barge, B., Meade C., Zhao X. (2016). Startup-yritysten kasvun ajurit ja pullonkaulat. (Growth factors and bottlenecks for business start-ups). Finnish Government 30/2016.

Lipman-Blumen, J. (1976). Toward a homosocial theory of sex roles: An explanation of the sex segregation of social institutions, Signs: Journal of Women in Culture and Society 1(3, Part 2): 15-31. doi: https://doi.org/10.1086/493272.

Lutgen-Sandvik, P. (2003). The communicative cycle of employee emotional abuse: Generation and regeneration of workplace mistreatment, Management Communication Quarterly 16(4): 471-501. doi: https://doi.org/10.1177\%2F0893318903251627.

Marlow, S., \& McAdam, M. (2012). Analyzing the influence of gender upon high-technology venturing within the context of business incubation, Entrepreneurship Theory and Practice 36(4): 655-676. doi: https://doi.org/10.1111\%2Fj.1540-6520.2010.00431.x.

Martin, J. (1994). The organization of exclusion: Institutionalization of sex inequality, gendered faculty jobs and gendered knowledge in organizational theory and research, Organization 1(2): 401-431. doi: https://doi.org/10.1177\%2F135050849412011.

Martin, P. Y. (2001). Mobilizing masculinities': women's experiences of men at work, Organization 8(4): 587-618. doi: https://doi.org/10.1177\%2F135050840184003.

Martin, P. Y. (2003). 'Said and done' versus ‘saying and doing' gendering practices, practicing gender at work, Gender \& Society 17(3): 342-366. doi: https://doi.org/10.1177\% 2F0891243203017003002. 
Monahan, T., \& Fisher, J. A. (2015). Strategies for obtaining access to secretive or guarded organizations, Journal of Contemporary Ethnography 44(6): 709-736. doi: https://doi. org/10.1177\%2F0891241614549834.

Neuman, J. H., \& Baron, R. A. (2005). Aggression in the Workplace: A Social-Psychological Perspective. In S. Fox \& P. E. Spector (Eds.), Counterproductive work behavior: Investigations of actors and targets (pp. 13-40). American Psychological Association. doi: https://doi.org/10.1037/10893-001.

Neyland, D. (2016). Challenges of Organizational Ethnography: reflecting on methodological insights. In F. Dykes and R. Flacking (Eds.) Ethnographic Research in Maternal and Child Health, (1 ed., pp. 179-198). London: Routledge.

Nowell, L. S. et al. (2017). 'Thematic Analysis: Striving to Meet the Trustworthiness Criteria', International Journal of Qualitative Methods. doi: https://doi.org/10.1177/16094069 17733847.

Queirós, A., Faria, D., \& Almeida, F. (2017). Strengths and limitations of qualitative and quantitative research methods. European Journal of Education Studies.

Ridgeway, C. L. (1997). Interaction and the conservation of gender inequality: Considering employment, American Sociological Review 218-235. doi: https://doi.org/10.2307/ 2657301.

Ries, E. (2017). The startup way: how modern companies use entrepreneurial management to transform culture and drive long-term growth. Currency.

Sanderson, K. (2017). Workplace ostracism: a critical discourse analysis of the lived experience.

Schein, E. H. (1983). The role of the founder in creating organizational culture, Organizational Dynamics 12(1): 13-28. doi: https://doi.org/10.1016/0090-2616(83)90023-2.

Schein, E. H. (2010). Organizational culture and leadership (Vol. 2), John Wiley \& Sons.

Serrat, O. (2017). The critical incident technique. In Knowledge Solutions (pp. 1077-1083). Springer, Singapore.

Stitt-Gohdes, W. L., Lambrecht, J. J., \& Redmann, D. H. (2000). The critical incident technique in job behavior research. Virginia Polytechnic Institute and State University.

Suryani, A. (2008). Comparing case study and ethnography as qualitative research approaches, Ilmu Komunikasi 5(1): 117-127. doi: https://doi.org/10.24002/jik.v5i1.221.

Sutton, S. M. (2000). The role of process in software start-up, IEEE Software 17(4): 33-39. doi: https://doi.org/10.1109/52.854066.

Tallberg, T. (2009). The gendered social organisation of defence: Two ethnographic case studies in the Finnish defence forces. Svenska handelshögskolan.

Tripathi, N., Seppänen, P., Boominathan, G., Oivo, M., \& Liukkunen, K. (2019). Insights into startup ecosystems through exploration of multi-vocal literature, Information and Software Technology 105: 56-77. doi: https://doi.org/10.1016/j.infsof.2018.08.005.

Wahl, A. (2014). Male managers challenging and reinforcing the male norm in management, NORA-Nordic Journal of Feminist and Gender Research 22(2): 131-146. doi: https:// doi.org/10.1080/08038740.2013.864702.

Watson, T. J. (2012). Making organisational ethnography, Journal of Organizational Ethnography. doi: https://doi.org/10.1108/20466741211220615.

West, C., \& Zimmerman, D. H. (1987). Doing gender, Gender \& Society 1(2): 125-151. doi: https://doi.org/10.1177/0891243287001002002.

Wynn, A. T., \& Correll, S. J. (2018). Puncturing the pipeline: Do technology companies alienate women in recruiting sessions? Social Studies of Science 48(1): 149-164. doi: https:// doi.org/10.1177/0306312718756766.

Young, I. M. (2003). The logic of masculinist protection: Reflections on the current security state, Signs: Journal of Women in Culture and Society 29(1): 1-25. doi: https://doi. org/10.1086/375708. 